\section{WOMEN AND IRRIGATION IN NEPAL: CONTEXT, ISSUES AND PROSPECTS}

Sujan Ghimire

\section{Background}

Gender norms in Nepal categorize farming as the men's domain. But studies exploring the social realities of women provide a different picture. Works by Acharya and Bennet (1981), show that Nepali women are involved in subsistence farm management activities and that the rural women's input into the farm activities (9.91 hours per day) is more than the men's (which is about 5.86 hours per day). Not only do women contribute labour in household and farm activities but also have influential roles in deciding certain activities such as crop seed selection, use of organic manure, choice of food for daily consumption etc. These studies also show that the decision-making roles of women and men vary with the types of activities undertaken and the types of ethnic group to which they belong. Studies - specifically exploring women's roles in irrigation - have also shown that rural women carry on different irrigation related activities. In the study on the Chhatis Mauja Irrigation Systems in Nepal, Zwarteveen et al (1993) write that female members of farms that are jointly managed by men and women are involved in irrigated agriculture. A study carried out by this researcher shows (1996) that women of the hills are involved in carrying out different irrigation tasks but their participation is limited to providing labour and have marginal role in the decision making process of irrigation.

During recent years, the Nepali government has acknowledged women as irrigators and has formulated policies for promoting women's participation in the irrigation sector. This paper explores the role of women in irrigation in two areas. It first looks at actual labour contribution and then examines their role in decisionmaking: The former relates to the different tasks done by women whereas the latter relates to their participation in the Water Users Associations (WUA). The paper then tries to examine the relevance of the major irrigation policies regarding the participation of women in irrigation. To understand the national irrigation concerns on women, a brief historical sketch of the major global concerns on women is undertaken.

\section{Introduction}

Irrigation in Nepal is conceived as men's work. This idea is based on societal gender norms. Some of the common norms relate to the idea that: irrigation is related with physically strenuous works in which kodali is frequently used, so the women being biologically weaker than the men, cannot and should not partake this activity; irrigation works take place outside the household domain and includes social interactions with the outsiders, so men can conduct this activity not women. A closer look into these stereotypes reflects the idea of male superiority in economic, social and political arenas. Empirical studies exploring women's role in agriculture (Acharya and Bennet, 1981) and irrigation in particular (Zwarteveen, M. 1993; Neupane, N. 1997; Ghimire, S. 1996 \& Dawadi,D. 1999) have explicitly shown that in spite the prevailing gender norms, women do take part in irrigation activities and will increasingly be involved in the future. 
Modernization has brought many changes in the traditional division of labour in Nepal. Agriculture, which is the main source of rural subsistence, is insufficient in sustaining livelihood. The poor resource base, fragmented landholdings, population growth, underemployment are some factors that compel people to migrate to Tarai or to the urban areas, in search of economic avenues. And it is the men who are more rapidly being drawn into the cash economy than the women. As more men leave their homes and farms to pursue economic pursuits, women are left in their homes to shoulder both the household works and the farm works. As irrigation is an integral part of agriculture, women will become more involved in irrigation and related activities.

Women perform both productive and reproductive works. Productive works are works that have economic value and include the production of commodities that are geared towards the market. Reproductive works are the domestic works of the household and are generally not considered "work" because these do not directly contribute to the production of tradable products (Zwarteveen, M. 1994). Common gender norms assume that women carry out only reproductive works in society and their productive roles are overlooked. As already mentioned, the concept of male superiority in different spheres has been largely instrumental in promoting this kind of view of social reality.

Not that this dominant view has not gone unchallenged. From as early as the mid- $19^{\text {th }}$ century the concept of male supremacy was challenged. As a result of this critique, many different types of knowledge are emerging which try to understand social realities. Many sociological and anthropological researches have shown that women's location in and experience of most situations is different from that of men. The situation is less privileged and unequal for the women. It is not only unequal but women are oppressed, restrained, used and abused by the men. Above all, women's experience of differences, inequality, and oppression varies by their social location. This type of knowledge has given rise to theories of gender differences, gender inequality and gender oppression (Ritzer, G. 1996). A pioneering work concerning women had been undertaken by Frederick Engels in "The Origins of the Family, Private Property and the State", in which he had sought to critically explain women's unequal position and oppression. He argued that women's subordination results not from her biology but from the social arrangements, which the society legitimizes like the institution of family.

\section{Global Concerns on Women}

Women's concerns began to be addressed to some extent with the formation of certain global institutions. The Commission on the Status of Women was established in 1946 under the auspices of the United Nations (UN) as a subsidiary body of the Economic and Social Council. This commission's role was to create guidelines and to formulate actions to improve the situation of women in the economic, political, social, cultural and educational fields. In the early 1950s, the UN called on governments to stop discrimination against women on the basis of race, sex, language and religion. The underlying emphasis of these concerns can be interpreted as being protective towards the women. During the 1960s, there were feminists' movements in North America and Western Europe, which was concerned with women's reproductive rights, violence against women, sex discrimination and freedom from sexual domination, etc. (Bhadra, 2001).

The protective concerns for the women of the 1960s began to be criticized in the 1970s. The seminal work by Easter Boserup (1970), explored women's role in the productive sphere. In her (now famous book) Women's Role in Economic Development, she 
examined the division of labour in African, Asian, Latin American countries - in the process of examining the works done by the women in these societies. She shows that women are involved in productive spheres and that they do contribute to the national economy. She argues that these facts have been largely ignored by development agencies. Boserup's study illustrated the negative effects of development interventions on women (Boserup, 1970). This insight brought about many changes in the perspective regarding women and development.

The UN declared the decade from 1975 to 1985 as the Women's Decade. This period led to the birth of Women In Development (WID) approach. The term, "Women in Development "(WID) was coined by the Women's Committee of the Chapter of the Society for International Development at Washington, D. C. With the WID approach the focus shifted from the reproductive roles of women to the productive roles. The main argument of this approach was that development interventions, by focusing on men only, have resulted in the marginalizing women from the development arena. To overcome this, the WID approach argued for the need to target women. It also emphasized women's access to services and technology. The policies and programmes of WID were targeted towards solving the practical needs of the women and improving their conditions.

The concept of WID came under attack by feminists who argued that the problem of women was more of equity in development rather than integration with development. Subsequently, the term Women And Development (WAD) replaced the WID concept. With the WAD advocacy, policies were formulated based upon equity; emphasis was given to women's equal participation in development and improving the conditions of women (Bhadra, C. 2001).
Since the late 1980s the acronym Gender and Development (GAD) has been gaining ground. One of the reasons for its popularity visa-vis the earlier acronyms is that it perceives the problem more holistically and the policy recommendations that follow seek to address concerns that relate not only to women, but to men as well. Gender is a socio-cultural construct that has variation within cultures and over time. GAD focuses on the roles of men and women because it is by analyzing the differences between the roles/ relationships of men and women that the discrepancy of men and women can be understood. Needless to say, the GAD approach focuses both on the productive and reproductive roles of women and tries to integrate men and women within the development process. GAD, it is argued tries to fulfill the strategic needs of women by empowering them and improving their position in society.

In Nepal, the global concerns of women have been reflected in different policies and programmes of the government as well as of the NGOs and INGOs. The WID policy was mentioned in the Fifth Development Plan (1975-1980). The WID approach helped rural Nepali women to satisfy their practical needs to some extent. The WAD approach helped women to be economically independent by providing credit, and skill. The Ninth Five-Year Plan stipulated many $\mathrm{GAD}$ policies and programmes by mainstreaming gender equality and women's empowerment in different sectors. (Pokheral, and Mishra, 2001). Irrigation has been one of the key sectors where concrete steps taken have been taken for towards strengthening the role of women.

Before, looking into the role and participation of women in irrigation, it is essential to understand how scholars conceptualize irrigation as an enterprise. It is also necessary to understand how irrigation in Nepal in general has been categorized. 


\section{Concept of Irrigation Management}

Based on the management of systems, irrigation in Nepal can be broadly categorized into two types: The Farmer Managed Irrigation Systems (FMIS) and the Agency Managed Irrigation Systems (AMIS). The FMIS in Nepal have had a longer history than the AMIS. For centuries the Nepali farmers have been managing irrigation systems without any outside help. It is estimated that over seventy percent of the irrigated land is irrigated by FMIS. AMIS have been launched by the Irrigation Department and are usually managed by some agency. Studies that have compared AMIS and FMIS have shown that FMIS have stronger water users group and are more efficient compared to AMIS (Pradhan, 1988). In AMIS the recent government policy initiative has been towards handing over part of the system management to the farmers. This policy is guided by the emphasis on a more participatory management program Thus for irrigation management to be more effective and efficient the users groups have a crucial role to play. It has already been mentioned that women are quite involved in agriculture and irrigation.

Prior to the entry of sociological and anthropological knowledge in irrigation, the enterprise was seen purely as a technical input to increase agricultural production and was understood in terms of engineering models. After the entry of knowledge from the social sciences, irrigation began to be viewed as a social process. As the noted sociologist Walter Coward points out, irrigation as a social process involves institutions and organizations that are fused together through roles (Coward, 1985). As a social enterprise the major social processes of irrigation consists: (1) Water Acquisition,

(2) Water Allocation and Distribution (3) System Maintenance (4) Resource Mobilization (5) Conflict Management (Sharma, 1992; Uprety, 1989). The subsequent section examines these processes in Nepal in more detail.

\section{Roles and Responsibilities of Women and Men in Different} Irrigation Activities

Water acquisition: This is the process of acquiring water from the water source. Studies show that men participate more than women in this process. The difficulties in reaching headworks, may be one important factor in limiting women's participation. But there are some instances of women participating in this activity. For example, if the family has to provide certain labour days and there are no men in the family to do so then the women may take part in this process. Or if there is paid labour then the women may partake for monetary gains (Ghimire, 1996).

Water allocation: Water allocation means assigning rights to users and determining who shall have how much of water (Uprety, 1989). If there is a WUA, then water is allocated according to the rules and procedures of the WUA. It is the executive committee of such association that lays down the related rules for water allocations at all levels, from the main branch to secondary till the tertiary levels. In the absence of the WUA, water is allocated usually according to the customary rules of irrigation. The main customary law prevalent in society is that the upper stream lands will have the first priority over the irrigation water. Only after the upper stream farmers irrigate their lands will the lower stream farmer have access to the irrigation water. Another customary law is that the water is allocated according to the size of the land of the farmer. But these customary laws are not usually practiced. Even in the presence of a formal WUA the rich and the powerful farmers usually have the upper hand in irrigation. Women do not have substantial role in deciding how much irrigation water to allocate and to whom.

Water distribution: Water distribution is the actual delivery of water to the fields. Women and men both are involved in this process. Men are more involved in distributing water at the main 
branch whereas the women are active in distributing water at the branch and field channel levels (Ghimire, 1996). If the irrigation canal passes near from their homesteads then women of all groups irrespective of class, ethnicity, class and household size and structure are involved in the distribution works. Sometimes in the absence of men in the households, the women of the hills, carry on night irrigation by forming small women-groups. But the distance of the fields and the canal is one important determining factor for this activity. It is only the upstream women farmers, who carry night irrigation. Women find it difficult to walk long distances from their homes in the dark due to both physical and social constraints (Ghimire, 1996).

System maintenance: System maintenance is the repairing and cleaning of the canal for regular and efficient water acquisition and water allocation (Uprety, L. 1989). Both men and women participate in this process. Women of those households, who do not have male family members and cannot also send hired labourers, participate by providing labour.

Resource mobilization: Resource mobilization is an important process of irrigation because it is only through effective mobilization of cash and labour material that an irrigation system can develop and be sustained for a long time (Uprety, 1989). Women of lower income groups usually provide labour. Sometimes women provide labour for more days than the men when constructed activities of the irrigation canal takes place under paid labor. Cash acts as an incentive for their participation (Ghimire, 1996). The fact that more women are involved in resource mobilization does not imply that women can take decisions regarding issues of resource mobilization. It is the executive committee of formal or informal farmer users association takes the necessary steps regarding what types of resources to be mobilized and how.

Conflict management: Disputes and conflicts usually occur among the farmers. Inadequate and unequal water, nocturnal stealing of water, etc. are some of the main causes, which give rise to ill feelings and disputes. If there is a WUA, then it is according to the rules of the WUA that the culprits are punished (Uprety, 1989 \& Ghimire, 1996).

Studies that have examined the processes outlined above have shown that both women and men are involved in irrigation and related works (Zwarteveen, 1994; Ghimire, 1996; Neupane, 1997; Dawadi, 2001). The levels and types of participation of men and women vary. And participation even varies among and between women. Men participate both in labour contribution and decisionmaking process whereas women participate more in labour contribution and do so negligibly in decision-making. Until and unless women are involved in the water users association, which is the deciding body regarding irrigation water, it cannot be said that women are effectively participating in irrigation process. The Nepali government, through the specific legislations it has passed, has acknowledged that Nepali women are engaged in irrigation and related works. For instance, the Irrigation Policy 1992 states that there should be at least 20 percent women members in the general body of the WUA. The general members of the WUA are the heads of those households who have land in the command area of the irrigation canal. Thus, only the women having land registered in their names become the general members of the WUA.

But being general members does not guarantee the participation of women in the proceedings of the WUA. For instance, the elderly widows might have land registered in their names but it is their adult sons that conduct all agricultural activities. These old women 
do not take part in the WUA meetings; their sons represent them. Then legal documents may identify women as landowners but this may be due to the fact that their husband/s, father/s, in-law/s, brother/s have more land than prescribed by the land ceilings and so in order to escape land taxation, these may have been registered in their wives', sisters', daughters', daughters'-in-law names. (This has frequently been observed in the Tarai). These types of women automatically become the general members of the WUA but do not usually have any interest to participate in the WUA. The aforementioned category of women might not even know that they are the general members of the WUA. On the other hand there are some young widows, separated wives, de facto women heads whose husbands/men in the family have migrated out for work. These women are the ones who are most involved in irrigation and related works. But they might not have landholdings in their names and subsequently cannot be the members of the WUA. In case of men also, there may be tenants (men) cultivating lands of absentee landlords. The landlords become the WUA members though they may rarely come to the farms except to collect their agricultural rents. In such cases, the tenants conduct all the irrigation activities but they have no say in the WUAs (Ghimire, forthcoming). The policy which states that there should be 20 percent women members in the WUA association, seen in this light, seems to be a lame instrument for promoting women's participation in irrigation.

It need not come as a surprise that the formulation of this policy (that stipulates a certain percentage of the WUA to be women) in Nepal coincides with the period of the global popularity of the GAD concept, within the development arena generally and in the third world countries particularly. In 1992, there was the Dublin Conference on Water and it was followed by a number of conferences emphasizing women's role in water. Accordingly, The Water Resources Act 1992, Irrigation Policy 1992, Irrigation Policy
2002, have addressed women. The Water Resource Act (1992) is seen to be working towards providing equity to women concerning the domestic use of water. Article 7(1) of this Act provides the order of priority that should be followed in utilizing water resource. Water for drinking and domestic purposes is listed as the top priority followed by irrigation, agricultural, hydroelectricity uses etc. The women in Nepal generally fetch water for drinking purposes and for domestic use. Studies have shown that women use the water of the irrigation canal for domestic use also (Ghimire, 1996). If the irrigation canal passes by the household, then the women of that household use the water for washing clothes, dishes, watering and bathing cattle. This is particularly true if the household is poor and does not have its own water source. Studies (Ghimire, forthcoming) have also noted that after the WUA has been formed, the main priority goes to irrigation water and women who had been previously using the water are deprived access. There are no means to safeguard the needs of these women though it is legally stated that water for drinking and domestic purpose should be given the first priority.

Similarly, the Irrigation Policy (1992) has made provision to include women users in the water users associations but it has done so in an incomplete manner. It assumes 'women' as a homogenous group and overlooks the differences and needs of different categories of women. Going still further, the Irrigation Policy 2002 states that in the Water Executive Committee (WUC) there should be at least two female members. But this policy also does not define membership criteria nor does it categorize the types of women who should be the executive member; neither does it say anything about the selection or the appointment criteria. Studies (Ghimire, S. forthcoming) that have examined women in irrigation have already noted that there are different categories of female members in the WUA and that their participation in the WUA varies accordingly. It 
is not sufficient to say 'women' should be involved in the WUA and in the WUC; it is necessary to define which types of women and to lay down the criteria for their selection.

Researches in irrigation have shown that the men in the WUA generally do not properly communicate about the agendas and proceedings to the women members. Not being fully aware of what is happening, the women do not feel inclined to attend the WUA general meetings; when they do attend the WUA general meetings, women are usually hesitant to speak out their irrigation needs and problems (Ghimire, 1996; Dawadi, 1999; Udas, 2002). It is usually assumed by women that they have to be "educated" and "eloquent" to give their opinion in such large gatherings.

\section{Prevailing Situation and Overcoming the Impasse}

Women participate and will continue to participate in irrigation works as more men migrate to urban areas in search of economic alternatives. But it is not all that all women are engaged in irrigation. It is usually the poor women of nuclear families, whose husband/family members has/have migrated out in search of other economical avenues, or separated women or young widows with children who perform irrigation works (Ghimire, 1996; Dawadi, 1999). These women are mostly young and married women with little or no education. There is a need to strengthen this group's participation in the decision making process by involving them in the WUC (and not 'women' in general). Studies (Sharma, S. 2001) have also shown that those who qualify for the leadership positions in the WUC are those who come from well off households and have the time to pursue community activities; they are not tied by domestic chores, can travel to the district headquarters when required and are educated and can communicate with outsiders. Studies have shown that it is those who can speak the bikas language made possible sometimes by their higher educational attainment and at other times by prior involvement in government offices and at other times by involvement in student politics at school and college levels, that usually occupy such positions (Sharma, S. 2001). In this context, the representation of women in bodies such as the WUA and the WUC has been simply a token to bring in other powerful men (namely their husbands) by proxy.

It has also been observed that in the pretext of involving (according to a fixed quota) women, it is usually the educated women of higher class that are selected as members. This category of women is more often than not, educated, vocal, have time and resources for traveling but might not in fact represent the needs of the actual women irrigators. Initiatives to enhance participation should try to reflect the women irrigators' needs, interests and their workload.

Studies(Ghimire, forthcoming) have shown that women who are involved in irrigation disseminate information of the proceedings of the WUA informally. These women either go to their neighbours or relatives to discuss their irrigation needs and problems. If some sort of informal smaller committees can be formed within the larger WUA bodies, the women would certainly feel more free and convenient to discuss their problems. It has been clearly demonstrated that women do better than men in conducting small credit and income generating activities. Unfortunately, in irrigation related activities, women's involvement does not directly provide them with monetary returns. If involvement in irrigation can be linked with credit, such as multipurpose type of co-operation, then women might be stimulated to participate in irrigation management. However, in the name of development and participation, women should not be forced to sacrifice the little extra time they have had for themselves. 


\section{Women and Irrigation: Balancing Practical With Strategic Needs}

Nepali women are substantially involved in irrigation. Their participation varies with their household structure and other social factors. Generally speaking, it is the women who come from nuclear families, those who have less amount of irrigated land, have little or no education that are mainly involved in irrigation works. Their involvement, is, however, limited to labour works and have a marginal role, including decision-making, in WUA. The Irrigation Policy 1992, has tried to work towards equity concerning women by stating that 20 percent of the general members should be women. The Irrigation Policy 2002 has moved in the direction of empowering women by stating that in the WUC, out of the 9 members 2 should be women. These steps are commendable. There are, however, gaps between the intentions of the policies and the social reality.

This makes it relevant to take into cognizance both the practical as well as strategic needs in formulating policies that aim to strengthen women's role in society. As related to irrigation, getting adequate, equal and timely irrigation water are some important practical needs of the women. Likewise, having access to the water of the irrigation canal for domestic use is also another important practical need of the women. If women become the WUC members they can act towards safeguarding their water rights. But the tenure of the WUC membership is such that not all people can qualify to become the members. Representation of women in WUC addresses the larger strategic needs of women. While endeavors at the micro levels are geared towards satisfying the practical needs of women, the women's social movement taking place in Nepal is concerned with their larger, longer-term strategic gender needs. At this juncture it is necessary to see the practical and strategic needs of women as complementary and convergent and not as divergent or working at cross purposes. More research needs to be done on how incentives (such as those stipulated in the Irrigation Policy) could address their immediate practical needs as well as work towards fulfilling women's larger strategic gender needs as well.

\section{Note}

The paper mainly deals with the findings of the research on women and irrigation, conducted by the author over the years. In particular, one research was conducted in the hills (unpublished Masters' thesis) and the other in the Tarai. I express my gratitude to The International Irrigation Management Institute (IIMI) for providing me the grant to conduct the research in the hills and to The Nepal Water Conservation Foundation (NWCF) for enabling me to conduct the study in the Tarai. The editorial inputs provided by Dr. Sudhindra Sharma are duly acknowledged.

\section{Reference Cited}

Acharya, M and Bennet, L. 1981 The Rural Women of Nepal-An Aggregate Analysis and Summary of 8 Villages, Studies in The Status of Women in Nepal (vol. 2, Part 9) CEDA, Kathmandu.

Bhadra, C. 2001 Gender and Development: Global Debate On Nepal's Development Agenda in Contributions To Nepalese Studies (Vol. 28, Nov, 1), CNAS Kathmandu.

Boserup E. 1970 Women's Role in Economic Development, New York, St. Martin's Press.

Coward, W. 1985 Technical and Social Change in Current Irrigated Regions: Rules, Roles and Rehabilitation in Putting People First, Edited by Carnea, Oxford University Press.

Dawadi, D. 1999 Women's Participation and.Water Rights, A Case Study of West Gandak Irrigation System. Unpublished Thesis, Tribhuvan University. 
Engels, F. 1970 The Origins of the Family, Private Property and the State. New York, International Publishers.

Ghimire, S. S 1996 The Role of Women in Irrigation A Case Study of Angutar Kulo, Unpublished thesis, Tribhuvan University, Kathmandu.

Ghimire, S.S. forthcoming Women in Irrigation: A Gender Perspective. Nepal Water Conservation Foundation. Kathmandu.

His Majesty's Government of Nepal, 1995 Irrigation Policy Ministry of Water Resources, Singha Durbar, Kathmandu.

His Majesty's Government of Nepal, 2000 Water Resource Act, 1992, Water Resource Regulation 1993, Water Resources Regulation 2000 (Nepali). Legal Book Management Committee, Ministry of Law, Justice and Governance.

Neupane, N. 1993 A Case Study in Chhatis Mauja on Gender and Irrigation. Research Report. IWMI, Kathmandu

Pokheral, B. and Mishra, M. 2001 Gender and Democracy in Nepal, edited by Manandhar and Bhattachan. Central Department of Home Science, Women's Studies Program. Tribhuvan University and Friedrich-Ebert- Stiftung.

Pradhan, U. 1988 Local Resource Mobilization and Government Intervention in Hill Irrigation Systems in Nepal, Water Management Synthesis Project, USAID.

Regmi,C. S. 2000 Gender Issues in the Management of Water Projects in Nepal A Thesis submitted for the Doctor of Philosophy, Faculty of Engineering and Applied Sciences, Department of Civil and Environmental Engineering, Institute of Irrigation and Developmental Studies, University of Southampton.

Ritzer, G. 1996 Modern Sociological Theory, The McGraw-Hill Companies, Inc.

Sharma, S. 2001 Procuring Water: Foreign Aid and Rural Water Supply in Nepal, Nepal Water Conservation Foundation. Kathmandu.

Sharma, S. 1992, The Role of Organizer in Participatory Irrigation Programs in Nepal Unpublished Thesis, Ateneo De Manila University.
Udas, P. 2002 Gender and Policy on FMIS in the Changed Context in the Farmer Managed Irrigation Systems In The Changed Context, edited by Pradhan and Gautam. Farmer Managed Irrigation Systems Promotion Trust, Kathmandu.

Upretty P, L. 1989 Indigenous Irrigation Systems in Nepal A Case Study of a Hill Village, Unpublished Thesis, Ateneo De Manila University.

Zwarteveen M. 1994. Gender Issues, Water Issues-A Gender Perspective in Irrigation Management, International Irrigation Management Institute.

Zwarteveen, M. 1993 A Gender Perspective in Irrigation Management International Irrigation Management Institute, Kathmandu 